\title{
Liberdade de imprensa: margens e definições para a democracia durante o governo de Juscelino Kubitschek (1956-1960)
}

\author{
Flavia Biroli ${ }^{1}$ \\ Instituto de Ciência Política — UnB
}

\section{RESUMO}

Este artigo analisa aspectos das relações entre imprensa e política durante o governo de Juscelino Kubitschek (19561960), com especial atenção para os debates em torno do projeto de lei de imprensa apresentado pelo governo ao Congresso Nacional em outubro de 1956. O projeto, que não chegou a ser votado, mobilizou discussões que ocuparam as páginas dos grandes jornais e fizeram parte das sessões do Congresso por mais de dois meses, permitindo observar os sentidos assumidos pela noção de democracia e o papel nela atribuído à imprensa naquele momento. Os debates suscitados permitem ainda apreender aspectos da prática e do pensamento político das elites brasileiras no período, em meio a um debate específico e que implicou a assunção de posições concretas pelos envolvidos.

Palavras-chave: Governo Kubitschek (1956-1960); Democracia; Imprensa.

\section{ABSTRACT}

This study analyzes some aspects related to press and politics in Juscelino Kubitschek's government (1956-1960), focusing the debates or the project of a new press law presented by the government to the National Congress in October 1956. Although the project was never voted, it was the theme for debates that were in the papers and in Congress for over two months, creating the possibility to analyze the meanings assumed by the notion of democracy and the role projected to the press in democratic politics at that moment. Those debates have also turned into an interesting material to the study of political practices and thoughts mobilized by Brazilian elites in that period.

Keywords: Kubitschek's government (1956-1960); Democracy; Press. 
Este artigo trata das relações entre imprensa e política durante o governo de Juscelino Kubitschek, enfocando, em especial, o debate ocorrido no segundo semestre de 1956, quando o governo apresentou ao Congresso um novo projeto de lei de imprensa. O projeto não chegou a ser votado, mas o debate a seu respeito, que ocupou as páginas dos principais jornais durante mais de dois meses, merece atenção por mobilizar, como aspecto central da luta política, a atribuição de sentidos à própria democracia e ao papel nela desempenhado pela imprensa.

Não abordarei, neste caso, a liberdade de imprensa como conceito ou atributo de um regime democrático que poderia ser medido pela extensão do exercício dessa liberdade. Interessa-me, sim, o modo como os discursos em sua defesa (tanto por parte do governo quanto dos parlamentares e empresas jornalísticas que se opuseram ao projeto) revelaram percepções e aspectos da prática e do pensamento político das elites brasileiras no período, em meio a um debate específico e que implicou a assunção de posições concretas pelos envolvidos.

Antes de entrar efetivamente naquele debate, no entanto, faço um convite ao leitor para que me acompanhe em uma exposição de aspectos importantes do jornalismo e da política nos anos 50, especialmente aqueles que se referem ao intervalo entre 1954 e 1956, que permitirão uma melhor abordagem da temática principal deste texto.

\section{TRAMANDO IMAGENS E MEMÓRIAS: O GOVERNO JK E A IMPRENSA}

Pouco depois do encerramento de seu mandato como presidente da República, na noite de 21 de janeiro de 1961, Juscelino Kubitschek foi recebido na Associação Brasileira de Imprensa - ABI, que oferecia, na ocasião, um banquete em sua homenagem. Alguns trechos do noticiário acerca desse evento, tais como foram publicados no primeiro número do Indicador dos profissionais da imprensa daquele ano, expõem pontos e fios interessantes que compõem a trama que proponho tratar neste ensaio. $\mathrm{O}$ título da notícia, "O adeus (com mágoa) de JK", e o destaque abaixo da foto de Kubitschek, "cinco anos de absoluto respeito à liberdade de pensamento", para recortar por enquanto apenas o mais superficial, são complementados pelo que se lê no primeiro parágrafo do texto: o ex-presidente fora recebido pelos jornalistas para agradecer o apoio por eles concedido a seu governo, mas também para falar-lhes de "sua mágoa em face da posição negativista tomada por determinada impren- 
sa ante o atual esforço empreendido pelo povo brasileiro para libertar-se das amarras do subdesenvolvimentismo e lançar-se decididamente ao encontro de seu destino histórico".

Estendo-me ainda um pouco nessa notícia, reproduzindo um trecho do discurso proferido pelo então presidente da ABI, Herbert Moses, no qual se podem entrever alguns aspectos interessantes do imaginário que se afirmaria, posteriormente, a respeito do governo Kubitschek e que, nesse caso específico, faz-se também por meio da temática enfocada neste artigo, a das relações entre imprensa e governo. Vamos às palavras de Moses:

O governo Kubitschek não foi apenas um período de trabalho intenso, de dinamismo administrativo, de desenvolvimento apaixonado: foi também o governo em que a imprensa pôde usar mais livremente os seus direitos ... A imprensa opinou livremente, informou livremente, criticou livremente. Muitas críticas teriam sido exageradas, muitas excessivas, muitas injustas, com certeza. Mas exageradas ou excessivas ou injustas, puderam ser formuladas, tiveram livre curso, não tiveram sanções. ${ }^{3}$

Desenvolvimento e dinamismo, liberdade e democracia: parecem ser esses os termos que compõem, até o presente, a imagem predominante de Kubitschek e seu governo. Trabalhada, como indiquei, desde o momento em que se encerrava seu mandato presidencial, essa imagem foi reforçada e auxiliada pelo fato de que JK e seu governo participaram da composição de um período de vigência da democracia constitucional que o olhar posterior vê espremido diante das fronteiras da violência de duas ditaduras (a do Estado Novo e a do pós64). A percepção "em bloco" dos anos entre 1945 e 1964 como período democrático, marcado pela intensidade do desenvolvimento e dos debates públicos, não me parece esgotar, no entanto, a força e capacidade de renovação da imagem política de Kubitschek, como atestam adesivos pregados aos vidros de alguns carros na cidade de Brasília, trazendo o dístico "JK, procura-se outro", discursos proferidos pelos principais candidatos às últimas eleições presidenciais ${ }^{4}$ ou publicações recentes com destaque no mercado editorial. ${ }^{5}$

Também muitos estudos históricos e sociológicos tendem a destacar, daquele momento, o desenvolvimento acelerado e a amplitude das mudanças e da liberdade que deviam envolver a "atmosfera" do período, fazendo-o de forma que torna muito difícil determinar onde terminam as projeções políticas da época e onde se iniciam memórias (muitas vezes saudosas) e perspectivas 
analíticas, elas mesmas enredadas, ainda que em níveis diferentes, por essas memórias. ${ }^{6}$

As imagens predominantes fortalecem-se na medida em que cultivam, em relação ao período, a idéia de uma suposta homogeneidade. Daí a possibilidade de falar-se em democracia, liberdade, desenvolvimento ou esperança, em retrospectiva, como "identificadores" da atmosfera daquele período, deixando de lado, muitas vezes, os impasses e conflitos em torno dos sentidos assumidos por essas noções na luta política de então. Esse efeito de planificação está presente nas afirmações do presidente da ABI, Herbert Moses, tecidas no calor da hora e reproduzidas há pouco, mas também em afirmações feitas em análises posteriores. Cito exemplos extraídos de dois estudos recentes, dos quais o segundo diz respeito especificamente ao tema deste texto.

Vamos ao primeiro deles. Lucília de Almeida Neves, em ensaio no qual discute o trabalhismo e sua ênfase reformista nos anos 1945-1964, afirma que foi peculiar àquele período "um forte sentido de esperança, caracterizado por uma marcante consciência da capacidade de intervenção humana sobre a dinâmica da História, buscando-se implementar um projeto de nação comprometido principalmente com o desenvolvimento social". A história brasileira a partir dos anos 40 mas, em especial, durante os anos 50, teria tido como marca especial a "crença na transformação do presente com o objetivo de construção de um futuro alternativo ao próprio presente". A Ainda que a autora ressalte que os projetos aos quais se refere em seu texto, vinculados em especial ao PTB, não foram unívocos nem homogêneos, indicando ambigüidades e paradoxos - o trabalhismo teria significado ao mesmo tempo dirigismo, paternalismo e potencial de autonomia para sujeitos históricos; teria havido aperfeiçoamento do capitalismo, mas também possibilidades de aproximação com o socialismo reformista etc. —, seu texto traz uma série de afirmações semelhantes às já destacadas, que atribuem ao período uma "atmosfera" possível a partir da exposição de algumas das práticas que o constituíram, participando por vezes do efeito de planificação de que falávamos. É o caso, por exemplo, da afirmação de que o "tempo do trabalhismo" traduziu-se em um programa assim caracterizado:

[seu] principal ingrediente era a crença na resolução dos problemas sociais do país, na superação do subdesenvolvimento que assolava a economia brasileira e na construção de uma nação mais soberana. Tudo isto a ser alcançado por um processo pacifista, ou seja, pela via legal do reformismo. Se tal proposição era utópica ou mesmo contraditória, não deixou de ser marcada por uma forte ge- 
nerosidade e solidariedade social, inimagináveis no tempo presente, marcado por um outro signo: o do individualismo. ${ }^{8}$

Em um outro exemplo, agora mais próximo de nossa temática, a da liberdade de imprensa, Celso Lafer, questionando o sentido da persistência de Juscelino no imaginário político brasileiro e a razão de ser da "crescente unanimidade" em torno de sua figura política, fornece, entre outras, a seguinte resposta:

Coerente com o seu diagnóstico, que via o problema brasileiro como uma crise de puberdade e não de velhice, JK promoveu política e economicamente o desenvolvimento do país. Politicamente, impulsionou a democratização, estimulando com admirável tolerância o livre exercício da palavra viva e vivida no espaço público da vida brasileira. Daí, aliás, o clima de efervescência cultural que assinalou a sua presidência. ${ }^{9}$

Neste texto, por caminhos diversos daqueles que foram tomados pelos autores citados, dou destaque à questão das relações entre imprensa e política durante o governo de Juscelino Kubitschek e, nela, à problemática da liberdade de imprensa, como parte de um esforço maior no sentido de buscar as fraturas do imaginário homogeneizado ao qual me referi há pouco. Assim, à idéia de liberdade plena associada ao governo JK ou aos anos 50, adiciono o debate acerca do projeto de lei de imprensa apresentado ao Congresso pelo Executivo no dia 9 de outubro de 1956. Adiciono, ainda, a Portaria 899, baixada pelo governo JK no mesmo mês, buscando regular politicamente o conteúdo veiculado por rádio e televisão, acompanhada do debate a seu respeito. Parto, portanto, não da legalidade reformista e dos impulsos no sentido da democratização como traços assumidos do período, mas de discussões que expõem a tensão em torno do próprio sentido da legalidade e da democracia naquele momento.

Gostaria de fazer duas observações introdutórias sobre o objeto deste estudo.

A primeira diz respeito à escassez de referências feitas aos episódios citados, inclusive nos estudos voltados para uma história da imprensa ou para uma discussão sobre a democracia vigente no período. ${ }^{10}$ Ainda que a imprensa (ou alguns veículos em particular) apareça, tantas vezes, como material de fundo de uma série de pesquisas, são poucas as análises que a tomam como parte ativa na composição e formatação dos próprios temas e debates políti- 
cos que "relata" - isto é, como personagem do cotidiano político e simbólico presente em suas páginas, em relação ao qual assume uma suposta exterioridade.

A segunda observação, mais relacionada à perspectiva de trabalho aqui assumida, refere-se ao fato de que não recorro às práticas restritivas à liberdade de imprensa como contraponto simples à imagem de liberdade ampla cultivada pela memória predominante acerca dos anos 50 e do governo JK. Não considero que seja uma questão de contraposição, em que o dourado com o qual foram pintados aqueles anos cederia espaço ao cinza. Volto-me para essa problemática, entretanto, com o objetivo de flagrar momentos conflituosos, em que os esforços de atribuição de sentidos (ao governo, à própria democracia ou ao papel nela desempenhado pela chamada imprensa livre) são, como disse no início deste texto, parte central da luta política.

Além do que já foi dito, é preciso ressaltar que os debates para os quais se volta este estudo permitem observar a presença de matizes das tradições de pensamento das elites no Brasil, com destaque para a tradição liberal, que fornece boa parte do terreno e das "lentes" por meio das quais a questão das relações entre imprensa e política é visualizada diante da circunstância concreta de defesa ou oposição ao projeto de lei apresentado pelo governo.

\section{IMPRENSA E POLÍTICA: A TESSITURA DAS CRISES}

União e desagregação: foi este o título de um editorial do jornal carioca Tribuna da Imprensa, publicado em 31 de dezembro de 1954. O jornal pertencente a Carlos Lacerda falava de uma primeira conseqüência da candidatura de Juscelino Kubitschek, a pouco menos de dez meses das eleições presidenciais de 1955. Como se sabe, a candidatura de Kubitschek (Partido Social Democrata - PSD) e, depois, sua eleição para a presidência, acompanhado de João Goulart (Partido Trabalhista Brasileiro — PTB) na vice-presidência, sofreu oposição e tentativas de veto inicialmente por parte de setores do próprio PSD, mas, em especial, por parte de setores militares e da União Democrática Nacional — UDN, com uma liderança agressiva do jornalista e deputado recém-eleito Carlos Lacerda (UDN-DF).

A conseqüência à qual se referia Lacerda naquele momento, e já em um contexto de forte oposição à possibilidade de que JK, então governador de Minas Gerais, fosse candidato pelo PSD à presidência, ${ }^{11}$ era a "quebra da unidade da imprensa livre" - unidade esta que, segundo o jornalista, havia sido 
"instrumento eficaz de transformação do Brasil" e era agora atingida pela oposição do Diário Carioca e do Correio da Manhã às soluções (e ameaças) militaristas levantadas contra a candidatura de Kubitschek. Os mesmos jornais manifestariam, em pouco tempo, seu apoio a Kubitschek, no que estiveram acompanhados, entre os jornais da chamada grande imprensa, do Última Hora de Samuel Wainer. ${ }^{12}$ Voltariam a se unir nas críticas no segundo semestre de 1956, durante o debate sobre o projeto de lei de imprensa proposto pelo governo, do qual apenas o Última Hora, entre os jornais de maior circulação do eixo Rio-São Paulo, procurou ausentar-se.

No texto da Tribuna, no entanto, a referência à "união da imprensa para a transformação" dizia respeito a episódios que se sintetizavam na oposição então recente da maior parte da grande imprensa ao varguismo, pontuada pela campanha pela derrocada do Estado Novo, pela campanha pró-Eduardo Gomes (UDN) nas eleições presidenciais de 1945, e pela oposição, em coro, à candidatura de Getúlio Vargas e a seu governo constituído após a vitória nas eleições de 1950. Durante a crise de agosto de 1954, que antecedeu o suicídio de Vargas, muitos desses jornais, entre eles o Correio da Manhã, que agora apoiava a candidatura Kubitschek, fizeram uma oposição explícita e agressiva ao ex-ditador, acusando-o de desmando e expondo a corrupção generalizada e o "caos" em que supostamente encontrava-se o país. Exigiam sua retirada da presidência e, como fariam outras vezes (em 1955 e em 1964, por exemplo), recorriam às Forças Armadas, que teriam responsabilidade e capacidade para a solução da crise. Com a morte de Vargas, a presidência foi assumida por seu vice, João Café Filho (Partido Social Progressista — PSP), significando uma presença ampliada da UDN no controle do governo federal. A candidatura de JK implicava, portanto, a possibilidade de rompimento desse controle, ou, como preferia a oposição udenista, o retorno ao varguismo.

Anunciava-se aí o conflito que estaria presente durante toda a campanha e também no momento da eleição, de que sairiam vitoriosos JK e Jango, com a derrota da candidatura udenista do general Juarez Távora, seguido por Ademar de Barros (PSP) e Plínio Salgado (Partido Republicano Paulista PRP). Mais uma vez, e como ocorreria durante quase todo o período de 19451964, com exceção da eleição e fugaz presidência de Jânio Quadros, a maior parte da imprensa de maior tiragem e peso do país saía frustrada da consulta às urnas, acompanhada pela UDN, partido cuja identidade eleitoral fora construída com base no antivarguismo. ${ }^{13}$

Do ano de 1955, marcado por diversas tentativas da UDN de refrear a candidatura Kubitschek, destacamos um aspecto, ao qual retornaremos mais 
tarde: o expoente mais destacado e "público" dos oposicionistas, Carlos Lacerda, utilizou-se largamente da televisão, do rádio e de seu jornal em seus ataques contra JK. Deles buscou utilizar-se, ainda, quando seu intuito era vetar a posse dos eleitos, sendo, no entanto, interrompido pelo chamado contragolpe de 11 de novembro, que garantiria a posse e instauraria o estado de sítio no país a partir do dia 26 do mesmo mês. Lacerda optou, então, pelo auto-exílio, em Portugal e nos Estados Unidos, do qual retornaria apenas em outubro de 1956. Nesses dois momentos (a ida para o exílio e o retorno), a problemática central a este ensaio, a da liberdade de imprensa, inseriu-se fortemente no debate político vinculado ao governo Kubitschek.

Não quero, com esses comentários, assumir a perspectiva divulgada pelo próprio Lacerda, na época e em depoimentos posteriores, segundo a qual a censura se estabeleceu naqueles momentos acima de tudo para silenciá-lo. Não se pode, no entanto, negar que as aparições de Lacerda em programas televisivos, assim como a veiculação de seus discursos em programas de rádio, significassem um forte incômodo para aqueles por ele visados. Essas aparições iniciaram-se em 1953, durante a CPI do jornal Última Hora, especialmente na TV Tupi, palco para seus discursos inflamados contra Vargas e Samuel Wainer. Mais tarde, em agosto de 1955, Lacerda leria, em um programa da TV Rio, ${ }^{14}$ a chamada carta Brandi, visando acusar o então candidato à vice-presidência, João Goulart, de ligações ilícitas com o peronismo argentino - a carta, mais tarde, se revelaria falsa. A utilização política da TV, veículo inaugurado em 1950 com as primeiras transmissões da TV Tupi-pertencente aos Diários Associados, de Assis Chateaubriand -, era, então, uma novidade, uma "intervenção" de novo tipo nos confrontos e debates correntes.

Em 1955, durante o estado de sítio que resultou do contragolpe de 11 de novembro e que durou cerca de um mês e meio, foram os jornais impressos, no entanto, os mais atingidos pela censura. Nereu Ramos, então vice-presidente do Senado, que ocupava a presidência do país após o impedimento de Carlos Luz, ${ }^{15}$ dirigiu ele próprio a reunião do dia 28 de novembro, em que recebeu representantes dos jornais para a fixação das normas da censura e a exposição do tipo de "colaboração" que a imprensa deveria oferecer ao governo: a censura deveria, então, ser determinada pelos próprios jornais, sob a responsabilidade de seus diretores. Pouco depois, a partir do dia 8 de dezembro, essa fórmula seria substituída pela censura prévia, com a exigência de que cada página, após ser "fechada" pela redação, fosse encaminhada ao gabinete do executor do estado de sítio, coronel Orlando Geisel, no Ministério da Guerra, para aprovação. A desobediência a esta última regra levou à apreen- 
são de uma edição do Correio da Manhã, jornal que, como vimos, apoiou o 11 de novembro, assim como apoiara a candidatura e apoiaria a posse de Juscelino Kubitschek. A partir do dia 29 de dezembro foi determinado um novo critério, o da presença de um censor em cada redação, não sendo mais exigido o encaminhamento da prova das páginas ao Ministério da Guerra. ${ }^{16}$

Mais tarde, em 1956, é que as restrições se exerceriam com maior freqüência sobre o rádio e a televisão, de acordo com os termos da Portaria 899, da qual falaremos adiante.

Esta breve incursão pelos anos de 1954 e 1955 teve como objetivo mapear os preâmbulos dos debates de 1956, a serem trabalhados a seguir.

\section{EM DEFESA DA ORDEM}

No dia 9 de outubro de 1956, quando foi encaminhado ao Congresso Nacional o projeto de lei de imprensa elaborado pelo governo, a mensagem presidencial que o acompanhou expunha, da perspectiva do Executivo, sua importância. Reproduzida por alguns jornais e citada muitas vezes durante os debates posteriores, a mensagem de Juscelino Kubitschek ressaltava a necessidade de atualização dos direitos e deveres da imprensa diante dos novos tempos e das alegadas deficiências da lei anterior (nº 2083, de 12/11/1953), criticada por sua

incapacidade de atingir os objetivos superiores de valorizar a verdadeira imprensa, como a expressão da opinião pública e também na sua elevada categoria de serviço público. Na mesma proporção esse texto legal se mostra insuficiente como instrumento de defesa da segurança do Estado e do sistema constitucional em face da imprensa subversiva e fomentadora de desordens. Outra de suas deficiências, menos prejudicial talvez à integridade do regime, mas não menos nociva, é a que possibilita a facilidade ou a irresponsabilidade na prática de injuriar, difamar e caluniar, produzindo evidente degradação dos nobres processos de expressão do pensamento, pela palavra escrita ou falada. ${ }^{17}$

A mensagem apresenta também, visivelmente, respostas e contra-argumentos às críticas por parte da imprensa e da oposição, que começaram muito antes da apresentação do projeto. Desde agosto de 1956, puderam ser lidas em vários jornais referências ao projeto de lei de imprensa que estava em elaboração, baseadas, todas elas, em informações dispersas ou em especulações acerca dos termos do projeto. O "projeto rolha" ou a "lei de arrocho", expres- 
sões comuns nos jornais cariocas e paulistas, restringiria a liberdade de imprensa, implicando, portanto, um ataque à própria democracia, que teria naquela liberdade um de seus pilares mais básicos. Essa percepção da indissociabilidade entre democracia e liberdade de imprensa, que não problematiza os sentidos de nenhum dos termos e, menos ainda, o de sua relação necessária, esteve presente também na mensagem de Kubitschek, na qual, no entanto, o aspecto central é a distinção entre a boa e a má imprensa, entre os princípios da ordem e os da desordem, da conservação e da subversão. Foram estas as oposições por meio das quais a mensagem presidencial afirmou, simultaneamente, a defesa da liberdade de imprensa — "nunca me ocorreu a idéia ou o cálculo de uma nova lei que viesse esmagar direitos e prerrogativas que são inerentes ao princípio da própria existência da imprensa, num regime democrático" - e a necessidade de restrições em relação a ela, baseada em dois argumentos, em especial. O primeiro deles, fundado no princípio da ordem; o segundo, fundado na contraposição entre um liberalismo supostamente ultrapassado e um liberalismo de novo tipo. Ambos seriam debatidos e criticados, como veremos, sem que, no entanto, fosse abandonado o terreno construído pela pressuposição da relação necessária (e universal) entre democracia e imprensa livre, entre jornalismo e crítica nas sociedades modernas.

A nova lei permitiria, segundo a mensagem presidencial, que não se confundisse o jornalista digno com "o profissional dos insultos inconseqüentes ou da pregação delirante contra as instituições estabelecidas no texto constitucional". Teria como pressuposto fundamental a defesa da "integridade do Estado", negando a "liberdade intolerável” e o "odioso privilégio" assim expresso: "o de pregar-se pela imprensa ou pelo rádio a desordem nas ruas, a subversão do regime, a destruição ou a substituição violenta das instituições legitimamente e legalmente constituídas no texto da Constituição e na continuidade histórica de nossa formação democrática”. Como sintetizava a mensagem, o princípio da ordem pública estaria sendo colocado acima de qualquer outro.

É também nesse sentido que se constrói o segundo argumento central, anunciado antes, o da contraposição entre o velho e o novo liberalismo. Lembro que a percepção de que o país se encontrava em um momento de modernização, lida como progressão segundo um desenvolvimento que deixaria para trás o "Brasil velho", foi bastante utilizada pelo governo Kubitschek, sempre vinculada à temática da conservação da ordem pública. Fez, também, parte do campo argumentativo da época. Modernizar significou, em uma definição bastante ampla e sintética, transformar sem alterações que implicassem a 
transgressão da ordem, esta também enunciada em sentido amplo. Na mensagem que encaminhou o projeto de lei de imprensa ao Congresso, ordem e transformação associam-se de uma maneira bastante peculiar. Diagnosticamse os novos tempos e a necessidade de transformação se faz, neste caso, baseada no próprio princípio da ordem. Juscelino afirma que seu governo se identifica com o princípio liberal que vê na imprensa livre um pilar básico da democracia, mas segundo princípios "mais concretos e menos individualistas" do que aqueles "tradicionais e clássicos princípios de liberdade de imprensa do século XIX”. Sem discutir esses tradicionais e clássicos princípios, a mensagem presidencial os sintetiza, também sem particularizá-los, nos "princípios espirituais que permitiam a liberdade ilimitada e mesmo irresponsável do antigo liberalismo", aos quais, então, dever-se-ia adicionar e impor

também os elementos materiais, que condicionam a liberdade em leis de interesse geral e a limitam pelas condições de organização social dos nossos regimes e pela estrutura política das nossas sociedades — tudo vem de acordo com as necessidades da nossa época e segundo as condições do mundo moderno.

Nessa formulação, extraída em parte do estudo de Claude-Albert Colliard ("Précis de droit public et des libertés publiques") citado pela mensagem presidencial, assim como em formulações presentes em mensagens e discursos de Kubitschek durante seu governo, podemos levantar, primeiramente, a hipótese da existência de uma subordinação formal do princípio da liberdade ao da preservação da ordem, expressa como ordem pública (manutenção do Estado) e ordem material (a ordem vista como necessária ao avanço do capitalismo industrial no país). Essa mesma hipótese pode ser plausível também para a relação entre liberdade e ordem presente na tradição liberal que, ao contrário do que afirma Kubitschek, não prescreve uma liberdade ilimitada e, menos ainda, livre do condicionamento dos tais "elementos materiais" por ele citados. Um exemplo claro (e clássico) está em Sobre a liberdade, de John Stuart Mill, publicado pela primeira vez em 1859. De modo semelhante ao que se pode ler no texto escrito dois séculos antes por John Milton, Areopagítica (1644), também expressivo da tradição liberal inglesa no que concerne à liberdade de expressão, Mill discorre sobre os limites entre a independência individual (liberdade de consciência, crença e opinião) e o controle social, defendendo que é por meio do confronto entre as diferentes opiniões e doutrinas que se faz possível a progressão da razão e do intelecto, assim como a correção das falsas opiniões e o acesso à verdade. Se a preserva- 
ção da capacidade de opinar dos indivíduos, em relação aos demais ou ao Estado, é um aspecto central nessa tradição liberal, há, no entanto, um outro, inseparável daquele, que vincula a expressão individual ao bem coletivo e, como tal, à norma (aos costumes ou à ordem em sentido amplo): a distinção entre self regarding conducts e other regarding conducts é, também, a distinção entre os casos em que deve haver "perfeita liberdade legal e social" e aqueles em que "a interferência da sociedade, para promover o bem-estar geral, torna-se aberta à discussão, pois aí a jurisdição do todo alcança o indivíduo”. O Estado não deve interferir quando a ação afeta apenas o indivíduo, neste caso a liberdade seria completa (silenciando sobre outras formas de disciplinamento e coerção existentes nas sociedades). A única liberdade que merece esse nome, segundo Mill, "é a de procurar o próprio bem pelo método próprio, enquanto não tentamos desapossar os outros do que é seu, ou impedir seus esforços para obtê-lo", o que sugere um outro aspecto importante presente na tradição liberal, a saber, o vínculo indissolúvel entre liberdade individual e defesa da propriedade privada. ${ }^{18}$ Ao negar os "velhos" princípios da tradição liberal do século XIX, Kubitschek não se distancia, de modo algum, da perspectiva nela presente e dos valores históricos que nela se materializam.

No caso de que trata este artigo, a negação da liberdade "irrestrita" deve ser visualizada, também, em seu aspecto político mais circunstancial. Em seu estudo sobre a ideologia do desenvolvimento em Juscelino e Jânio Quadros, Miriam Limoeiro Cardoso observa que a defesa da ordem figurou como um dos componentes ideológicos centrais durante a candidatura e governo de Juscelino Kubitschek. Ao mesmo tempo em que aponta, em diversos discursos do então presidente, que o desenvolvimento almejado não implicava rupturas, mas o "despertar" de forças latentes (imagem constante nos discursos de JK), destaca um outro aspecto bastante relevante para a discussão que desenvolvo aqui. Segundo a autora, "a defesa da ordem, da lei, da Constituição, do regime" equivalia, para Juscelino, na defesa de sua candidatura, de sua posse e de sua manutenção no governo durante o período para o qual fora eleito presidente. Juscelino "diz ser a ordem fundamental para o desenvolvimento, sabendo que ela é fundamental para o seu próprio exercício político", salienta Cardoso. ${ }^{19}$

Algumas publicações do período eleitoral de 1955 dão exemplos claros da questão a que se refere Cardoso e, com ênfase, da atuação da imprensa de oposição a Kubitschek. Exemplificam qual o referente político que dá sentido à expressão "liberdade intolerável" — para pregar a subversão pelos jornais ou pelo rádio - , por meio da qual Kubitschek justifica, não apenas o projeto 
de lei como um todo, mas o mais criticado de seus artigos, o artigo 40, que previa a apreensão das edições de jornais e revistas que contivessem conteúdo considerado subversivo ou de atentado à ordem pública, a ser determinada pelas autoridades policiais dos Estados. ${ }^{20}$

Para fornecer um exemplo claro das opiniões e "pregações" que o governo procurava evitar com a nova lei, recorro ao maior expoente da oposição partidária e jornalística a Kubitschek no período, Carlos Lacerda, ao qual já me referi. Em outubro, quinze dias depois da eleição que dera a vitória a JK e Jango, Lacerda escrevia:

Deve ser entregue o Poder ao usurpador, apenas porque ele teve o cuidado de mobilizar uns quantos votos, minoria da minoria? Vamos recomeçar, inutilizar todos os passos dados e sacrifícios feitos até agora, só para fingir que somos uma Democracia já desabrochada e perfeita?

Ao sr. Kubitschek queremos dizer que, pela sua candidatura, suas origens políticas, seus compromissos confessados e outros escondidos com o rabo de fora, suas inequívocas ligações com a Oligarquia Vargas, sua 'vitória' pífia, pequena porcentagem eleitoral entre os escassos $60 \%$ que compareceram para votar, ao sr. Kubitschek queremos dizer que lhe falta autoridade para falar como presidente da República.

Ele não é e não será presidente. ${ }^{21}$

Afirmações como essas seriam repetidas inúmeras vezes na Tribuna da Imprensa e no jornal O Estado de S. Paulo, sempre pronto a publicar ou divulgar escritos de Lacerda, ou em programas de rádio e televisão. Em uma edição da Tribuna de novembro de 1955, pouco antes do contragolpe que garantiria a posse dos eleitos, Lacerda diria ainda uma vez: "Juscelino e Jango não podem tomar posse". ${ }^{22}$

Essa situação de questionamento da legalidade do governo, que perduraria especialmente durante seu primeiro ano, e não apenas a oposição liderada por Lacerda, teve como uma de suas reações, por parte do governo eleito de Kubitschek, o projeto de lei de imprensa apresentado em 1956. No interior dessa mesma rede de conflitos foi elaborada a Portaria 899, baixada pelo então ministro da Viação, Lúcio Meira, e publicada no Diário Oficial de 8 de outubro de 1956 (um dia antes da apresentação do projeto de lei de imprensa ao Congresso). A Portaria introduzia as restrições nela presentes pela afirmação de que os serviços de radiodifusão, mesmo concedidos, permaneciam como serviços públicos e de responsabilidade do Estado, o qual deveria evitar 
que fossem utilizados para transmissões "obscenas, contrárias à moral, subversivas ou injuriosas", para "finalidades destrutivas e programas contrários aos interesses da sociedade”. Resumida em dois artigos, a Portaria determinava:

Art. $1^{\circ}$ : As estações radiodifusoras, inclusive as de televisão, excluirão dos seus programas as anedotas maliciosas, os gracejos picantes, bem como não irradiarão quaisquer manifestações, ainda que reprodução de artigos ou discursos, que importem ou possam importar na subversão da ordem pública, em incitamento a greves, que possam provocar a animosidade entre as classes armadas, ou delas contra as instituições civis; a instigação à desobediência coletiva ao cumprimento da Lei; ou que contenham injúria ou desrespeito às autoridades constituídas.

Art. $2^{\circ}$ : A infração ao disposto no artigo $1^{\circ}$ sujeita a empresa à suspensão de sua estação por prazo não excedente de 30 dias e, em caso de reincidência, à rescisão da concessão.

Destaco a combinação entre aspectos de conteúdo político, que podem ser referidos às circunstâncias mais imediatas de que falávamos — reprodução de artigos ou discursos que pudessem provocar a subversão da ordem ou a animosidade entre as classes armadas ou delas contra as instituições vigentes - , e aspectos de conteúdo moral — as anedotas maliciosas e os gracejos picantes - justificados também, no texto introdutório da Portaria 899, pelos “apelos públicos das autoridades civis e eclesiásticas" devidos à alegada "influência nociva para a formação da juventude" da difusão de anedotas, histórias ou cenas impróprias.

É interessante constatar que a Portaria seria criticada pela oposição em razão do cerceamento de discursos de conteúdo político mais imediato, em especial no que se refere à reprodução de discursos feitos no Congresso ou à presença de seus expoentes, como o próprio Carlos Lacerda, em programas de rádio e televisão. Nesse sentido, Lacerda diria: "Uma democracia em que só uns podem falar no rádio e outros, em pleno uso de seus direitos de cidadania, não podem falar ao povo senão nos limites de sua presença pessoal, é tudo menos democracia. Uma 'legalidade' que assim se impõe é tudo menos legalidade".23 Não seriam feitas, no entanto, nos espaços da oposição "legitimada" (por meio de jornais e discursos no Congresso), críticas ao cerceamento de conteúdo moral prescrito pela Portaria. No que se refere à moralidade ou a apelos culturais para a conservação de costumes, governo e oposição "legitimada" parecem situar-se em um mesmo campo valorativo, como se pode ler, por exemplo, em uma notícia presente no jornal O Estado de S. Paulo, representativa de outras 
notas e textos presentes na grande imprensa da época. O jornal, um dos mais explícitos opositores da candidatura Kubitschek, e, posteriormente, do projeto de lei de imprensa apresentado pelo governo, assim como da Portaria à qual me refiro, levantava acusações contra programas de televisão que seguiam, segundo o texto, tendência já expressa nos programas de rádio ("o rádio, regra geral, descambou"). Falando contra os "gracejos indecentes" e os "trejeitos indecorosos" exibidos em programas televisivos que constituiriam manifestações de incivilidade e infrações de normas regulamentares, o jornal dirigia-se aos dirigentes das estações de radiodifusão, pedindo-lhes bom-senso, e aos "responsáveis pelo policiamento dos divertimentos públicos", pedindo-lhes que "entrem em ação quando o bom critério falhar, ou a vigilância, que existe nas estações de televisão, for burlada”. A televisão, nas palavras do texto, não poderia ser convertida em "agente da dissolução dos costumes, para agravar a frouxidão atual e contaminar até a adolescência e a infância”. ${ }^{24}$

Levanto este ponto, o das divergências políticas e convergências no âmbito que poderíamos classificar como moral, ou como cultural em sentido mais amplo, para introduzir uma questão que me parece relevante. A defesa da liberdade e sua regulamentação em nome da ordem, tais como aparecem nos documentos lidos e analisados, expõem conflitos importantes para a compreensão do jogo político naquele momento, mas escondem ou escamoteiam a presença de outros conflitos, não menos importantes, que dizem respeito também ao que "pode ser dito", mas que nos remetem às práticas cotidianas de cerceamento que compõem toda a produção simbólica nas sociedades e que constituem, de modo peculiar, a produção da chamada "imprensa livre" - os meios de comunicação de propriedade ou controle privado, nas sociedades capitalistas industriais ou em vias de industrialização.

\section{IMPRENSA LIVRE E OPINIÃO PÚBLICA: SENTIDOS PARA A DEMOCRACIA}

Nas formulações às quais tenho me referido, ficam silenciadas muitas das práticas de cerceamento que compõem cotidianamente a "ordem social".

No material trabalhado, referente aos debates de 1955 e 56, assim como na defesa da liberdade de expressão feita no texto de Stuart Mill, as opiniões individuais ou aquelas inscritas na imprensa são caracterizadas como independentes ou livres na medida em que não sofrem o controle ou cerceamento do Estado ou de "outrem", em discursos nos quais esse "outrem" representa outros indivíduos com igual capacidade e possibilidade de expressar-se e 
sustentar opinião, já que um dos aspectos básicos da perspectiva liberal é a visão de que a sociedade se faz de indivíduos iguais em capacidade (isto é, que supostamente "partem" de uma condição de igualdade em relação aos demais, enquanto seres livres e racionais).

A censura governamental à imprensa é, nesse mesmo terreno das formulações presentes na tradição liberal, vista como a negação da capacidade de discernimento dos indivíduos, de seu estatuto como sujeitos de opinião, como leitores ou como votantes, implicando uma ameaça à própria concepção de soberania popular que ancora a de democracia. Nas palavras de Tocqueville, escritas, como as de Mill, em meados do século XIX,

Num país em que reina ostensivamente o dogma da soberania do povo, a censura não é apenas um perigo, mas um grande absurdo. Quando se concede a cada qual um direito de governar a sociedade, cumpre reconhecer-lhe a capacidade de escolher entre as diferentes opiniões que agitam seus contemporâneos e apreciar os diferentes feitos cujo conhecimento pode guiá-lo. ${ }^{25}$

As reações ao projeto de lei de imprensa de 1956 e à Portaria 899 se fizeram por meio de formulações que remetem às circunstâncias políticas mais imediatas de sua produção, mas que se deixam flagrar em seus vínculos com a tradição liberal, tal como indicada aqui. Um editorial publicado no Correio da Manhã, jornal que defendera a candidatura e posse de Juscelino, é bastante significativo. Nele, o jornal sugere que os três poderes, Executivo, Legislativo e Judiciário, estariam sendo tutelados ou, nas palavras do texto, receberiam “ordens do $1^{\circ}$ Exército", o que conferiria à imprensa o estatuto não apenas de um quarto poder, mas do único poder livre e efetivamente crítico, responsável pela manutenção do regime democrático. A formulação, apesar de longa, merece ser reproduzida:

Na defesa do regime, está a imprensa. É o único poder que se opõe ao grupo militar que se agiganta para encher o lugar do presidente que se nanifica. É preciso sufocar a imprensa para que o regime democrático no Brasil fique convertido num corpo sem substância: só casca e aparência. É o que pretende o governo. A farsa democrática poderia continuar a ser representada. Não haveria mais quem denunciasse a farsa e os farsantes.

Não haveria mais perigo, realmente, de outro 24 de agosto. O governo poderia apodrecer em paz e se permitir o desplante de responsabilizar a imprensa pe- 
las crises que sacodem periodicamente o país, como fez o sr. Juscelino. Não haveria mais rios de lama, porque não haveria quem os denunciasse. Neste país, disse o presidente, os excessos da imprensa é que engendram as crises. Fim do seu raciocínio será portanto: feche-se a imprensa que as crises acabam. ${ }^{26}$

O jornal O Estado de S. Paulo trabalharia nessa mesma linha em suas críticas, as quais, no entanto, estiveram em continuidade com sua oposição à candidatura de Kubitschek, sempre vinculada a Vargas e à ditadura do Estado Novo. Para esse jornal paulista, o cerceamento à imprensa seria expressão daquelas práticas políticas e indício do risco anunciado de seu retorno. Seria essa a linha de argumentação do jornal durante todo o período entre 45 e 64, mesmo durante a articulação do golpe de 1964, na qual Júlio de Mesquita Fi-

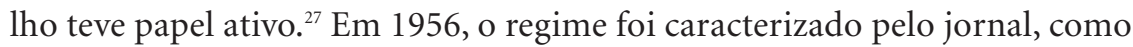
o seria também no início dos anos 60, como de "aparência democrática": as ameaças de apreensão de jornais e práticas de cerceamento da opinião seriam reveladoras de seu verdadeiro caráter, o da "tirania".

Uma nota editorial publicada em O Estado de S. Paulo no dia 2 de setembro de 1956, mais de um mês antes da apresentação do projeto ao Congresso, trabalhou sobre o argumento, também freqüente, de que, ao procurar censurar ou regular indevidamente a imprensa, o governo atacaria, na realidade, a opinião pública. "A imprensa é um simples veículo de informação e orientação popular. Os escândalos e os crimes que ela relata, não os forja nas redações", apenas os revela, dizia, afirmando que o intuito do governo seria, acima de tudo, aquele comum às ditaduras, isto é, o de impedir a opinião pública de conhecer quem são e o que pretendem, verdadeiramente, os que a governam.

A expressão "opinião pública" apareceria com freqüência durante o debate, carregando consigo uma tensão bastante presente nas percepções políticas encontradas em editoriais e notícias da época, que remetem, também aqui, a elementos da tradição política liberal: nessas percepções, é comum que o desprezo ou o receio às "massas" — algo que a análise depreende de uma série de textos publicados no período ${ }^{28}$ - conviva com a atribuição de uma posição central para a "opinião pública" na política. Vale a referência a Gabriel Tarde, para quem o "público" seria um estágio posterior em relação às massas, menos ameaçador e, ao mesmo tempo, determinante, e, como tal, potencialmente opressivo. ${ }^{29}$ No debate aqui abordado, o destaque à opinião pública como base real da política, como determinante dos interesses da sociedade, é peça-chave na construção de um lugar imprescindível para a imprensa, que 
seria o principal laço, a principal ponte, entre governo e público. A imprensa tornaria o exercício do governo transparente e compreensível ao público, tornando, em via oposta, as reivindicações do público visíveis para o governo. Constrói-se, assim, uma idéia de representatividade que não coincide com a representatividade eleitoral, mas que a ultrapassaria, sendo tratada como um "dado" das chamadas sociedades de massas.

Nessa linha, o texto de OESP dizia:

Não cabe exclusivamente à imprensa o protesto e a defesa contra este despótico atentado à sua liberdade; cabe também, e em maior parte ainda, ao próprio povo, já que ele tem nela o único porta-voz verdadeiramente desinteressado das suas reivindicações e dos seus direitos, a única tribuna onde pode livremente acusar e desmascarar os que roubam, enganam e desrespeitam. ${ }^{30}$

Os grandes jornais, assim como muitos jornalistas em publicações desvinculadas das empresas nas quais trabalhavam (livros, jornais sindicais, publicações resultantes de congressos de jornalistas), projetaram em seus discursos a auto-imagem de portadores dessa função/missão de tornar acessível a política, na qual acesso significaria informação, e não participação no sentido ativo, mesmo que no âmbito da opinião. A imprensa garantiria, assim, a visibilidade da política pela opinião pública, a qual, de outro modo, teria esse acesso negado ou seria levada a mistificações e não à realidade. O jornalismo teria, nesse sentido, a incrível missão de tornar pública a atividade que se supõe pública por excelência, a política. Daí ser descrito como atividade necessária à sobrevivência das sociedades modernas, como seus "olhos" e "pulmões", nas palavras de Rui Barbosa que foram tão citadas por jornais e jornalistas no período. $^{31}$

Essas imagens se sustentam e têm sua coerência discursiva baseada em estratégias de dissimulação do lugar de quem fala (do jornalista e do jornal como instituição), nas quais a imprensa é descrita como um "canal", um "meio" de apreensão, expressão e representação, em imagens que oscilam entre a ênfase na técnica e na imparcialidade e a ênfase em uma espécie de missão civilizatória, por meio da qual (e apenas por meio da qual) a democracia real poderia vir a tornar-se possível.

Ressalto, como indiquei antes, que a vinculação necessária e universal entre imprensa e liberdade, presente nas formulações que analisei, deixa descoberta uma multiplicidade de práticas que constituem a produção jornalística e as relações entre os meios de comunicação e a política. As redes e ma- 
lhas do controle social cotidiano presente em empresas privadas tais como jornais e outros meios de comunicação ficam, muitas vezes, delas excluídas. Ficam delas excluídas, também, as áreas de contato entre o jornalismo e a política, que não são transgressões ou desvios, mas constituem, em muitos aspectos, as duas atividades. Por mais que o entrelaçamento (tenso e mutável, é certo) entre essas atividades apareça com clareza em inúmeros momentos da história, e os anos 50 são repletos de exemplos nesse sentido, a projeção de um jornalismo imparcial e "exterior" aos confrontos políticos teve lugar central na construção de identidades para a prática jornalística no período, sendo peculiar aos anos 50 e 60 a percepção de um jornalismo mais técnico e posterior a sua "etapa política". Daí a idéia de que, sob o espectro da Democracia com "d" maiúsculo, confrontem-se tão-somente uma "imprensa livre" e apolítica (ou ao menos apartidária) e as tentativas de controle sobre ela por parte dos governos. ${ }^{32}$

Em um discurso feito no Congresso contra o projeto de lei de imprensa proposto pelo governo Kubitschek, posteriormente transformado em livro, Afonso Arinos (então deputado federal pela UDN-MG e professor de Direito da Universidade Nacional de Filosofia e da Faculdade de Direito do Rio de Janeiro) defendia a autonomia da imprensa em relação ao Estado, confrontando-se com a afirmação presente na mensagem de JK já trabalhada neste artigo, que justificava o projeto também por meio de uma caracterização da imprensa como "serviço público". Nesse ponto, Arinos é bastante enfático. Discorre sobre argumentos que atribui ao nazismo, ao fascismo e ao comunismo, nos quais a imprensa seria vista como representante do capitalismo e não da liberdade de imprensa. Seu ponto, dizia, não estava em negar o poder econômico sobre a imprensa, mas em defendê-lo, por sua diversidade de interesses, em relação ao controle monolítico do Estado sobre a opinião — "um poder econômico que atua sem oposição". Reproduzimos as seguintes palavras do deputado udenista, que teve atuação destacada durante os anos 50:

Quero me referir à presunção dos que sustentam que a imprensa privada impede grandes correntes de opinião de se fazerem ouvir, por falta de acesso aos jornais existentes e falta de recursos para a instalação de novos jornais. Esta objeção é em geral levantada de má fé, por ditatorialistas 'qui n'osent pas dire leur nom'. Mas como há crentes de boa-fé para tudo, convém respondê-la.

Em primeiro lugar é preciso que as opiniões sejam muito particulares, muito extravagantes mesmo, para que em toda gama de tendências da imprensa democrática não venham a encontrar acolhida em nenhuma. E a importância social 
de opiniões assim peculiares e extravagantes já seria bem duvidosa. Socialmente elas são valiosas como as que não conseguem se arregimentar em número suficiente para conseguir representação nas assembléias eletivas. Do ponto de vista democrático são, pois, irrelevantes. ${ }^{33}$

Vejamos, então: a liberdade de opinião excluiria, legitimamente, as opiniões tão "extravagantes", tão "particulares" a ponto de serem consideradas irrelevantes. Sua irrelevância corresponderia, assim, a sua falta de representatividade do ponto de vista eleitoral. O terreno democrático teria, desse modo, seu pluralismo "legítimo". À margem dele — e à margem da ordem que ele constitui - estariam, apenas, extravagâncias, e não silêncios e marginalidades, que poderiam compor visões alternativas à ordem estabelecida. Um exemplo concreto, no período, e também, talvez, o mais fácil de citar (já que outros nem mesmo assumem o caráter de personagens ou temas históricos), é a ilegalidade do Partido Comunista, excluído da democracia em argumentos que o definem como ameaça potencial a ela.

Fica colocada a tensão - a falácia, se preferirem - estrutural da concepção liberal de liberdade de opinião, vinculada à liberdade política. A liberdade da maioria, assim como a representação política da maioria, excluiria as idéias (e a participação política) de minorias que não atingissem a representatividade, assim como excluiria projetos e perspectivas que pudessem ser considerados ameaçadores aos valores vigentes. Para jogar com uma afirmação antes citada de Lucília de Almeida Neves, talvez se possa dizer que a construção de um futuro alternativo ao presente se projeta aqui apenas na medida em que as alternativas não ultrapassem certos limites, ou satisfaçam alguns dos valores e idéias predominantes no presente que se deseja ultrapassar mas também, em alguns aspectos, manter.

Ao justificar os limites entre o que pode ser manifestado e o que fica à margem do "público", o argumento utilizado por Afonso Arinos exclui, para dizer o mínimo, o processo de constituição das assim chamadas "maiorias" e "minorias", ou das opiniões e práticas que têm representatividade, do horizonte da argumentação. Essa exclusão se deve, por sua vez, ao fato de que a coerência interna dessa doutrina se baseia no pressuposto implícito da existência de uma sociedade de iguais em capacidade e razão, o que silencia ou atenua o fato de que os conflitos de poder e a submissão de uns a outros constituem as relações de força dessa sociedade. O confronto entre governo e "imprensa livre", expresso dentro dos limites de uma certa ordem política e moral (também no que se refere às tradições do pensamento político), como 
procurei indicar, silencia sobre perspectivas dele excluídas (e excluídas do próprio debate e da crítica "pública" no episódio analisado), já que, para utilizar a expressão de Afonso Arinos, situa-se no espaço das "tendências da imprensa democrática", que não representa, como se sabe, a totalidade das perspectivas existentes em uma sociedade em um dado momento.

A uma situação hipotética, na qual todos tivessem iguais condições de manifestação e ação política, poderia corresponder a imagem do "livre mercado de opiniões", cara ao pensamento liberal. Na medida em que não se trata de uma utopia, entretanto, mas de uma doutrina que tem seu funcionamento em sociedades conflitivas e desiguais, é que se faz necessário atentar para os limites restritos da concepção de liberdade mobilizada no debate de que tratamos. Em um outro momento, Afonso Arinos utilizaria uma expressão que denunciaria, ainda uma vez, esses limites: tratava-se, dizia, no liberalismo do século XIX assim como no do século XX, da "luta da liberdade jurídica contra a opressão do Poder" ${ }^{34}$ Deslocado o conflito para uma suposta oposição entre Liberdade e Poder, a liberdade se assentaria confortavelmente à definição de "liberdade jurídica", na qual os pressupostos da norma e da lei, a saber, a relação entre liberdade e propriedade, ficam do lado de fora do campo de problematização.

Pierre Bourdieu, ao discutir a prática da censura, trabalha em uma perspectiva diferente desta que venho indicando como presente nos debates da época - nos quais existem muitas continuidades entre os argumentos a favor da lei de imprensa (governo JK e aliados) e aqueles que a ela se opõem (UDN, Partido Libertador, a maior parte da grande imprensa), já que parecem, todos eles, situar-se em um mesmo "fluxo" das tradições do pensamento político; opõem-se, sim, mas como parte de uma situação política que faz confrontarem-se argumentos tecidos dos mesmos fios, quando a temática é a da liberdade de imprensa.

Para Bourdieu, "toda expressão é um ajustamento entre um interesse expressivo e uma censura constituída pela estrutura do campo em que ocorre esta expressão", fazendo que aquilo que se produz em um determinado campo (no caso específico de que tratamos, o do jornalismo, em seus vínculos com o da política institucional) seja resultado de "um acordo de compromisso, uma combinação do que era para ser dito, que tinha como objetivo ser dito, e do que poderia ser dito dada a estrutura constitutiva de um certo campo". ${ }^{35}$ E isso, adiciono, depende não apenas de estruturas que se constroem em durações mais longas (a imprensa como empresa nas sociedades capitalistas), mas também das circunstâncias históricas específicas (no espaço e no 
tempo). Dessa perspectiva, com a qual concordo, torna-se necessário pensar a imprensa, e o jornalismo, como campos constituídos por relações de poder que vão das hierarquias no interior das redações de jornal até a inserção social (ou de classe) dos jornalistas, das relações entre os proprietários dos meios de comunicação e a situação político-institucional circunstancial até as opções e vinculações político-partidárias de proprietários, diretores, chefes de seção (ou editores, na caracterização recente), redatores etc.

Em uma de suas críticas à Portaria 899, o jornalista e deputado Carlos Lacerda dizia que, de acordo com as restrições nela prescritas, "o que está negado não é apenas, a alguns, o direito de falar. É, a todos, o direito de ouvir". ${ }^{36}$ Pode-se pensar, no entanto, que na mesma medida em que não se trata, efetivamente, de uma sociedade na qual os indivíduos tenham iguais possibilidades de acesso aos espaços por meio dos quais suas opiniões poderiam ser tornadas "públicas", até mesmo o "direito de ouvir" se encontra delimitado por hierarquizações, silêncios e eufemismos, enfim, pelas barreiras entre o que se tinha por objetivo dizer e o que pode ser dito. E essas barreiras, como procurei indicar neste texto, mostram-se dinâmicas (porque históricas e políticas), apresentando-se como efeitos de inúmeras relações de poder que constituem os campos em que se produzem discursos - e não apenas como efeitos de embates entre duas "entidades", Governo e Imprensa Livre. Trata-se, diferentemente, de interações sociais constituídas por relações de poder que selecionam, positivam ou excluem sujeitos, temas e sentidos, ainda que os indivíduos sejam parte ativa dessas interações e, como tal, das próprias interdições sociais às quais, no entanto, não podem subtrair-se. Ainda segundo Bourdieu, as condições sociais (e, acrescentamos, econômicas e políticas) de constituição do campo em que são produzidos os discursos deixam passar aquilo que “é conveniente, que é dizível”, e excluem “o que não pode ser dito, dada a estrutura da distribuição dos meios de expressão, o indizível, e o que poderia muito bem ser dito, quase demasiado facilmente, mas que é censurado, o inominável". ${ }^{37}$

A discussão aqui desenvolvida não objetiva negar à chamada "imprensa livre" uma atuação expressiva (na qual atitudes possíveis de independência em relação a governos não significam, no entanto, apartidarismo, imparcialidade ou missão desinteressada) e, menos ainda, negar a existência de um papel para a imprensa no difícil processo de construção da democracia no país - o que não significa que esse papel deva ser tomado como "positivo" e "dado", mas que deve, sim, ser discutido, na medida em que se faz de discursos e práticas como aqueles de que tratei neste texto, de enfrentamentos, e também 
da participação ativa em episódios políticos imprescindíveis para a compreensão do que se passou entre o ensaio e o golpe, entre a crise política que culminou no suicídio de Vargas, em 1954, e a interrupção da legalidade democrático-eleitoral, como o golpe de 64 .

Pretendi, também, indicar, a partir dos debates sobre os quais trabalhei, um problema crucial para a discussão sobre jornalismo e política no período enfocado e, de modo mais amplo, nas sociedades contemporâneas. A saber, a possibilidade de questionar e problematizar os limites e descontinuidades existentes entre a chamada "liberdade de imprensa" e a "liberdade de manifestação" como direito generalizado, vinculado à intensificação do debate efetivamente público. Refiro-me, assim, à possibilidade de se problematizar e expor as fronteiras que determinam o que se situa do lado de dentro e o que se situa do lado de fora dessa liberdade de imprensa, proclamada básica, assim como à possibilidade de se questionar as margens e sentidos da concepção de democracia dela indissociável.

De uma perspectiva analítica e histórica, os questionamentos aos quais me refiro podem ser feitos por meio da explicitação das dissimulações — da perspectiva de quem fala — dos silêncios — implícitos na idéia de que a "imprensa livre" traz em si todo o leque das opiniões e perspectivas que constituem as sociedades em um dado momento - , assim como de alguns "fantasmas" - Imprensa Livre e Democracia, enunciadas como "entidades". Uma vez explicitados (dissimulações, silêncios e "fantasmas"), ficamos diante da tarefa, complexa, de visualizar e analisar os sentidos que assumem na história e nas tradições de pensamento com as quais dialogamos, assim como os elementos de conflito que os compõem.

\section{NOTAS}

${ }^{1}$ Professora Recém-Doutora do Instituto de Ciência Política da UnB. Doutora em História pela Unicamp.

${ }^{2}$ Indicador dos Profissionais da Imprensa, ano VI, n.10, jan./mar. 1961, p.11.

${ }^{3}$ Ibidem.

${ }^{4}$ A comemoração dos cem anos de nascimento de Juscelino, ocorrida durante o período de campanha presidencial de 2002, levou os principais candidatos (Lula, José Serra, Ciro Gomes e Garotinho) a referências acerca do governo JK. Chama a atenção o fato de que tenham sido feitas em termos semelhantes, situando-se em um mesmo campo de imagens e memórias. Para além das diferenças entre os candidatos, todas as referências trouxeram 
palavras como desenvolvimento e esperança, como bem exemplifica o discurso feito pelo então candidato Luiz Inácio Lula da Silva, em Diamantina, no qual definia Juscelino como aquele que "convenceu o Brasil de que tudo estava por fazer". Cf. www.lula.org.br/noticias, 13.09.2002 (acesso em out. 2002).

${ }^{5}$ Refiro-me a SANTOS, J. F. dos. Feliz 1958: o ano que não devia terminar. Rio de Janeiro: Record, 1998; e a BOJUNGA, C. JK: o artista do impossível. Rio de Janeiro: Objetiva, 2001.

${ }^{6} \mathrm{Em}$ minha tese de doutorado, realizei um mapeamento de estudos diversos, produzidos a partir dos anos 60, apontando para a centralidade do "progresso" técnico e do "desenvolvimento" em análises que estabelecem os anos 50 e, em especial, o período JK como traço divisório entre um Brasil que, supostamente, ficara para trás e um outro, o Brasil que se modernizava e impunha novas práticas e valores culturais, com ênfase para as transformações na política, no jornalismo e no trabalho. Cf. BIROLI TOKARSKI, Flávia M. Com a corrente: modernidade, democracia e seus sentidos no jornalismo brasileiro dos anos 1950. Doutorado em História, IFCH, Unicamp, junho de 2003.

${ }^{7}$ NEVES, L. de A. Trabalhismo, nacionalismo e desenvolvimentismo: um projeto para o Brasil (1945-1964). In: FERREIRA, J. (Org.) O populismo e sua história - debate e crítica. Rio de Janeiro: Civilização Brasileira, 2001, p.171.

${ }^{8}$ Ibidem, p.202.

${ }^{9}$ LAFER, C. Os anos JK: seu impacto e significado. In: Desafios: ética e política. São Paulo: Siciliano, 1995, p.112. Lembro que a imagem à qual recorreu Lafer é freqüente no imaginário acerca dos anos 50 e do governo JK. Durante a campanha presidencial de 2002, além do discurso de Lula, citado em nota anterior, o candidato pelo PSDB, José Serra, que disputou o segundo turno das eleições com Lula, falava de Juscelino como aquele que ensinou sua geração a "olhar para a frente" (Em "Serra: JK se fosse vivo seria tucano", www.joseserra.org.br/site/salaimprensa/noticias, 12.09.2002, acesso em out. 2002).

${ }^{10}$ As menções ao projeto de lei apresentado pelo governo JK, à oposição que sofreu por parte de toda a imprensa, ou ao debate a seu respeito, que ocupou as páginas dos jornais durante quase dois meses, são escassas e, quando existem, bastante breves, como no caso do estudo de Lúcia Hippólito sobre o Partido Social Democrata — PSD, um dos poucos a referir-se àquele episódio. Cf. HIPPOLITO, L. Raposas e reformistas: o PSD e a experiência democrática brasileira, 1945-1964. Rio de Janeiro: Paz e Terra, 1985.

${ }^{11}$ Para uma narrativa factual de eventos que ocorreram entre a morte de Vargas, em agosto de 1954, e a crise em torno da eleição de JK e Jango, cf. DULLES, J. F. Political military crises: 1955-64. Austin: University of Texas Press, 1970. Para discussões e análises sobre o segundo governo de Vargas (1951-54) e a crise que teve como desfecho o suicídio do então presidente, cf. os ensaios presentes em GOMES, A. de C. (Org.) Vargas e a crise dos anos 50. Rio de Janeiro: Relume-Dumará, 1994.

${ }^{12}$ O Diário, pertencente a José Eduardo de Macedo Soares, fez oposição a Vargas e seu governo, porém, após a morte do presidente, passou a relacionar-se estreitamente com os 
projetos de poder do PSD, apoiando a candidatura Kubitschek — seu redator-chefe, Danton Jobim, participou da campanha e durante o governo ocupou o cargo de presidente do IBGE. O Correio da Manhã, pertencente a Paulo Bittencourt, teve também trajetória de oposição a Vargas e, depois, conciliação de interesses com Kubitschek. O então redatorchefe do jornal, Álvaro Lins, teve participação intensa na campanha e, iniciado o governo, tornou-se Chefe da Casa Civil; o poeta, industrial e articulista do Correio, Augusto Frederico Schmidt, foi uma das figuras-chave do governo. Última Hora, por sua vez, manteve-se em uma mesma linha, passando do apoio incondicional a Vargas ao apoio à candidatura e governo de Juscelino e Jango: criado em 1951 com o apoio e apadrinhamento de Vargas, teria recebido empréstimos autorizados pelo então governador de Minas Gerais, Juscelino Kubitschek, como se pode ler em WAINER, S. Minha razão de viver. 16.ed. São Paulo: Record, 1998.

${ }^{13}$ A esse respeito, cf. BENEVIDES, M. V. A UDN e o udenismo: ambigüidades do liberalismo brasileiro. Rio de Janeiro: Paz e Terra, 1981.

${ }^{14}$ No dia em que o programa seria apresentado, a Tribuna da Imprensa foi às bancas com um convite para que seus leitores assistissem ao programa noturno da TV Rio. Essa mesma TV, mais adiante, em 1957, seria submetida a censuras e restrições como resposta ao programa Noite de Gala, no qual o jornalista Hélio Fernandes fazia críticas constantes à política do governo Kubitschek.

${ }^{15}$ Sobre o afastamento voluntário de Café Filho e a presença do então presidente da Câmara, Carlos Luz, na presidência da República, cf. DULLES, op. cit.

${ }^{16}$ Para além das mudanças na sistemática da censura, mantiveram-se as seguintes normas, divulgadas pelo governo no dia 28 de novembro: "NORMAS A OBEDECER: a) censura adequada sobretudo ao sentido jornalístico; b) permitir, de modo geral, a crítica aos atos políticos e administrativos do governo, desde que não envolva o propósito de subverter a ordem ou afetar as instituições; c) permitir o livre comentário sobre a política partidária, desde que não envolva os assuntos vetados; d) não permitir a crítica à legitimidade do atual governo ou à constitucionalidade das decisões do Congresso; e) não divulgar notícias referentes às Forças Armadas e a prisões ou atos decorrentes do estado de sítio, salvo se fornecidas ou autorizadas pelos gabinetes militares, pela Agência Nacional ou pelo executor do estado de sítio; f) não divulgar quaisquer notícias ou comentários que importem em estabelecer desarmonia entre as classes armadas ou entre estas e os poderes da República ou a opinião pública". A notícia a esse respeito foi manchete do Correio da Manhã do dia 29 de novembro de 1955, e as normas que transcrevemos foram publicadas na capa da mesma edição.

${ }^{17}$ Aqui, como adiante, refiro-me à mensagem presidencial de Juscelino Kubitschek ao Congresso Nacional tal como foi publicada no jornal O Estado de S. Paulo, 10/10/1956, p.5.

${ }^{18}$ MILL, J. S. Sobre a liberdade. Petrópolis: Vozes, 1991, p.53. E ainda: “O único propósito com o qual se legitima o exercício do poder sobre algum membro de uma comunidade ci- 
vilizada contra a sua vontade é impedir dano a outrem. O próprio bem do indivíduo, seja material seja moral, não constitui justificação suficiente. $O$ indivíduo não pode legitimamente ser compelido a fazer ou deixar de fazer alguma coisa, porque tal seja melhor para ele, porque tal o faça mais feliz, porque na opinião dos outros tal seja sábio ou reto. Essas são boas razões para o admoestar, para com ele discutir, para o persuadir, para o aconselhar, mas não para o coagir, ou para lhe infligir um mal caso aja de outra forma. Para justificar a coação ou penalidade, faz-se mister que a conduta de que se quer desviá-lo tenha em mira causar dano a outrem. A única parte da conduta por que alguém responde perante a sociedade é a que concerne aos outros".

${ }^{19}$ Cf. CARDOSO, M. L. Ideologia do desenvolvimento - Brasil: JK-JQ. 2.ed. Rio de Janeiro: Paz e Terra, 1978, p.157.

20 "Artigo $40-\mathrm{O}$ jornal que contiver propaganda de guerra, de processos violentos para subverter a ordem política e social, ou de preconceitos de raça ou classe, somente poderá ter a respectiva edição apreendida pela autoridade administrativa, em caso de urgência, para restabelecimento da ordem pública, e sujeito o ato de apreensão ao imediato reexame da autoridade judiciária. Parágrafo único - A apreensão será determinada pela autoridade policial mais graduada da Unidade da Federação em que estiver circulando o jornal, ou, nos Territórios Federais, pelo governador." E ainda: "Artigo 43 - o jornal que contiver propaganda subversiva (art.40), poderá ser apreendido, em caso de grave ameaça de perturbação da ordem pública, por ordem de um dos desembargadores e a requerimento do chefe do ministério Público da justiça local ou da autoridade policial a que se refere o parágrafo único do Art. 40." Segundo os termos do parágrafo único do Art. 43, fica prevista também a apreensão de jornais clandestinos ou "publicações de caráter obsceno".

${ }^{21}$ Tribuna da Imprensa, 17/10/1955. A "minoria da minoria", de que fala Lacerda, refere-se a dois argumentos bastante utilizados pela oposição à posse de Kubitschek. O primeiro refere-se ao fato de que JK teve 3.077.411 votos, enquanto os outros candidatos, somados, obtiveram 5.547.566 votos. O segundo, bastante alardeado por Lacerda, refere-se à aliança entre a candidatura JK-Jango e o Partido Comunista, então ilegal. Sem os votos dos comunistas, alegava Lacerda, JK e Jango não teriam sido eleitos.

${ }^{22}$ Tribuna da Imprensa, 9/11/1955. Além da oposição de parte da imprensa, de que destacamos o exemplo mais explícito, o governo de Juscelino sofreu também oposição por parte de setores militares, especialmente da Aeronáutica e da Marinha, com dois momentos de maior tensão: a revolta de Jacareacanga, em fevereiro de 1956, e a revolta de Aragarças, em dezembro de 1959.

${ }^{23}$ Tribuna da Imprensa, suplemento "Escravidão da palavra no Brasil: a censura no rádio e TV", 11/10/1957.

${ }^{24}$ O Estado de S. Paulo, "Um problema de televisão", seção “Notícias Diversas", 13/9/1955, p.11. 
${ }^{25}$ TOCQUEVILlE, A. de. Democracia na América. São Paulo: Martins Fontes, 1998, v.1, p.209.

${ }^{26}$ Correio da Manhã, 12/10/1956, p.6.

${ }^{27}$ Para a atuação de Mesquita na preparação do golpe, cf. BENEVIDES, op. cit., e KUCINSKI, B. "Os cem anos de vida do jornal O Estado de S. Paulo: liberal, conservador, antifascista”. Opinião, 3/1/1975, p.4-5.

${ }^{28}$ Esse aspecto foi bastante trabalhado na Parte 2, capítulo 2, de minha tese de doutorado. O caráter "fictício" da democracia foi, inúmeras vezes, atribuído em textos publicados nos jornais e em discursos de políticos (em especial udenistas) à ausência de um eleitorado consciente ou de eleitores "educados" de acordo com as exigências indispensáveis a uma "verdadeira" democracia. O mesmo foi, também muitas vezes, dito em relação às elites brasileiras: não haveria uma "verdadeira" democracia porque não havia, no poder, uma verdadeira elite; uma elite capaz de conduzir as massas, construindo, só então, uma democracia real. Muitas das formulações que analisei ecoam diagnósticos feitos para o Brasil por autores como Oliveira Vianna, nas décadas de 1930 e 40. Cf. BIROLI TOKARSKI, op. cit.

${ }^{29}$ TARDE, G. A opinião e a conversação (1899). In: A opinião e as massas. São Paulo: Martins Fontes, 1992.

${ }^{30}$ O Estado de S. Paulo. “O supremo objetivo”. Seção “Notas e Informações”, 2/9/1956, p.3.

${ }^{31}$ Cf. BARBOSA, R. A imprensa e o dever da verdade. (Coleção: Clássicos do jornalismo brasileiro.) São Paulo: Edusp, ComArte, 1990 (Conferência de 1920). Rui Barbosa foi bastante citado na imprensa, em argumentos contrários à participação decisiva dos militares na crise de 1955 ou no governo, em argumentos que discutiam os limites da legalidade, mas também, e especialmente, no debate de que trato aqui, que implicou a atribuição de uma missão e um papel específico para a imprensa na sociedade brasileira.

${ }^{32}$ Apesar de ser posterior, uma carta escrita por Júlio de Mesquita Filho a Carlos Lacerda pouco após o golpe de 1964 exemplifica de forma interessante o que venho dizendo, além de ferir fortemente a coerência desse discurso do apartidarismo e expor os conflitos em torno da noção de democracia. Nela, Mesquita procurava convencer Lacerda de que o mandato presidencial de Castelo Branco deveria ser prorrogado para três anos. O proprietário de $O$ Estado de S. Paulo afirmava que era favorável à candidatura de Lacerda, mas não em 65 , já que seria preciso, antes, consolidar a "nova democracia" e a economia brasileira. Nas palavras de Mesquita, "precisamos queimar até o último cartucho em defesa de uma oportunidade como a vitória de 31 de março, que não se repetirá nestes próximos cinqüenta anos" (12/5/1964). A análise dos jornais durante as crises de 54, 55, 61 e 64 expõe de modo bastante explícito o envolvimento entre o jornal paulista, a UDN e setores militares antivarguistas.

${ }^{33}$ MELO FRANCO, A. A. Pela liberdade de imprensa. Rio de Janeiro: J. Olympio, 1957.

${ }^{34}$ Ibidem, p.108. 
Flavia Biroli

${ }^{35}$ BOURDIEU, P. A censura. In: Questões de sociologia. Rio de Janeiro: Marco Zero, 1983, p.108.

${ }^{36}$ Tribuna da Imprensa, suplemento "Escravidão da palavra no Brasil: a censura no rádio e TV”, 11/10/1957.

${ }^{37}$ BOURDIEU, op. cit., p.109.

Artigo recebido em 2/2004. Aprovado em 5/2004 